\title{
Collateralized Assets Prices and Monetary Policy*
}

\author{
Received: November 02, 2018 - Accepted: May 08, 2019
}

Doi: http:/ /dx.doi.org/10.12804/revistas.urosario.edu.co/economia/a.8116

Mauricio Arango ${ }^{+}$

\begin{abstract}
A well-informed and cautious financial system can improve the welfare outcome of an economy by making lenders surplus to borrowers. Nevertheless, in a crisis, the behavior of the financial system can become an amplifier of it, given that credit approval conditions rarely meet the standards. Therefore, a credit crunch may occur even in a low-interest rates environment. This paper illustrates the aforementioned point by developing a general equilibrium model where the collateral credit condition defines the prudential behavior of the financial system. It and other conditions amplify the magnitude of a negative productivity shock.
\end{abstract}

Keywords: Monetary policy, credit, collateralized assets, general equilibrium. JEL Classification: E52, E58, G21

* I am thankful to Carlos Esteban Posada, Eduardo Morón, Luis Eduardo Arango, Carlos Andres Giraldo, anonymous referee, and participant at the XXVIII Uruguay's Central Bank Annual Conference, for all their useful comments.

+ Department of Economics University of Illinois at Urbana-Champaign. E-mail: arangoi2@illinois.edu

To quote this article: Arango, M. Collateralized Assets Prices and Monetary Policy. Revista de Economía del Rosario, 22(1), 155-185. Doi: http:/ /dx.doi.org/10.12804/revistas.urosario. edu.co/economia/a.8116 


\title{
Activos hipotecables y política monetaria
}

\author{
Resumen
}

Un sistema financiero bien informado y cauteloso puede mejorar el bienestar de una economía al canalizar los excedentes de los ahorradores a los prestatarios. Sin embargo, en una situación de crisis, el menor precio de bienes hipotecables limita la capacidad de crédito de la economía, generando la posibilidad de una reducción en el crédito inclusive en un escenario de bajas tasas de interés. Este documento ilustra el punto anteriormente mencionado através de un modelo de equilibrio general en el que el uso de activos como colateral determina que tan riesgoso es el comportamiento del sistema financiero. Esta y varias otras condiciones amplifican la magnitud de un choque de productividad negativo

Palabras clave: política monetaria, crédito, hipotecas, equilibrio general.

Clasificación JEL: E52, E58, G21

\section{Ativos Hipotecáveis e Política Monetária}

\section{Resumo}

Um sistema financeiro bem informado e cauteloso pode melhorar o bem-estar de uma economia ao canalizar os excedentes dos poupadores aos mutuários. No entanto, em uma situação de crise, o menor preço de bens hipotecáveis limita a capacidade de crédito da economia, gerando a possibilidade de uma redução no crédito inclusive em um cenário de baixas taxas de juros. Este documento ilustra o ponto anteriormente mencionado através de um modelo de equilíbrio geral no que o uso de ativos como colateral determina que tanto risco há no comportamento do sistema financeiro. Esta e várias outras condições amplificam a magnitude de um choque de produtividade negativo.

Palavras-chave: política monetária, crédito, hipotecas, equilíbrio geral.

Classificação JEL: E52, E58, G21 


\section{Introduction}

The 2008 financial crisis has reinforce the idea that the financial system has a considerable impact on the economic cycle and that a strong and sustained recovery must on a solid financial system. Nevertheless, recovery has been slow and highly expansive fiscal and monetary policies have done little to improve this. Credit recovery has become one of the main concerns of politicians, as expressed by the chairman of the Federal Reserve (FED), Ben S. Bernanke, in his declaration on June 7, 2012:

The depressed housing market has also been an important drag on the recovery. Despite historically low mortgage rates and high levels of affordability, many prospective home buyers cannot obtain mortgages, as lending standards have tightened and the creditworthiness of many potential borrowers has been impaired.

The behavior described in Bernanke's declaration has no precedent in the last two decades, as shown in figure 1. It also summarizes most of the purpose of this paper which is to develop a theoretical model that shows how changes in collateral constraints caused by both changes in the price of collateral and the cautious behavior of the banks can diminish monetary policy effectiveness by breaking the credit channel.

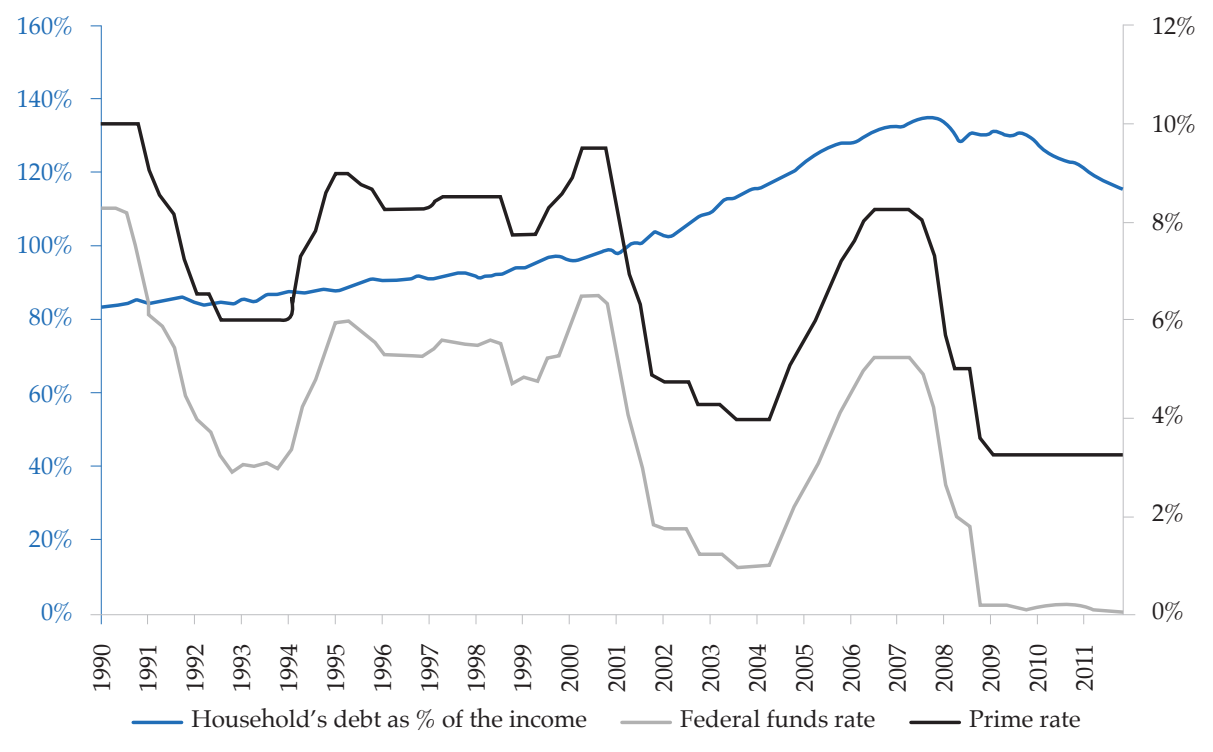

Figure 1. Household's Debt as \% of the Income and Interest Rates (Monthly) 
This slump in household credit has been one of the main reasons why the economic recovery has been slower than usual - similar references are found in Miller and Stiglitz (2010) Diamond and Rajan (2009), Mishkin (2009), Taylor (2009), and Brunnermeier (2008) - . As shown in figure $2,^{1}$ the US unemployment rate has never remained over $7 \%$ for very long in the last two decades. This implies a lower income for households and, therefore, lower consumption and welfare.

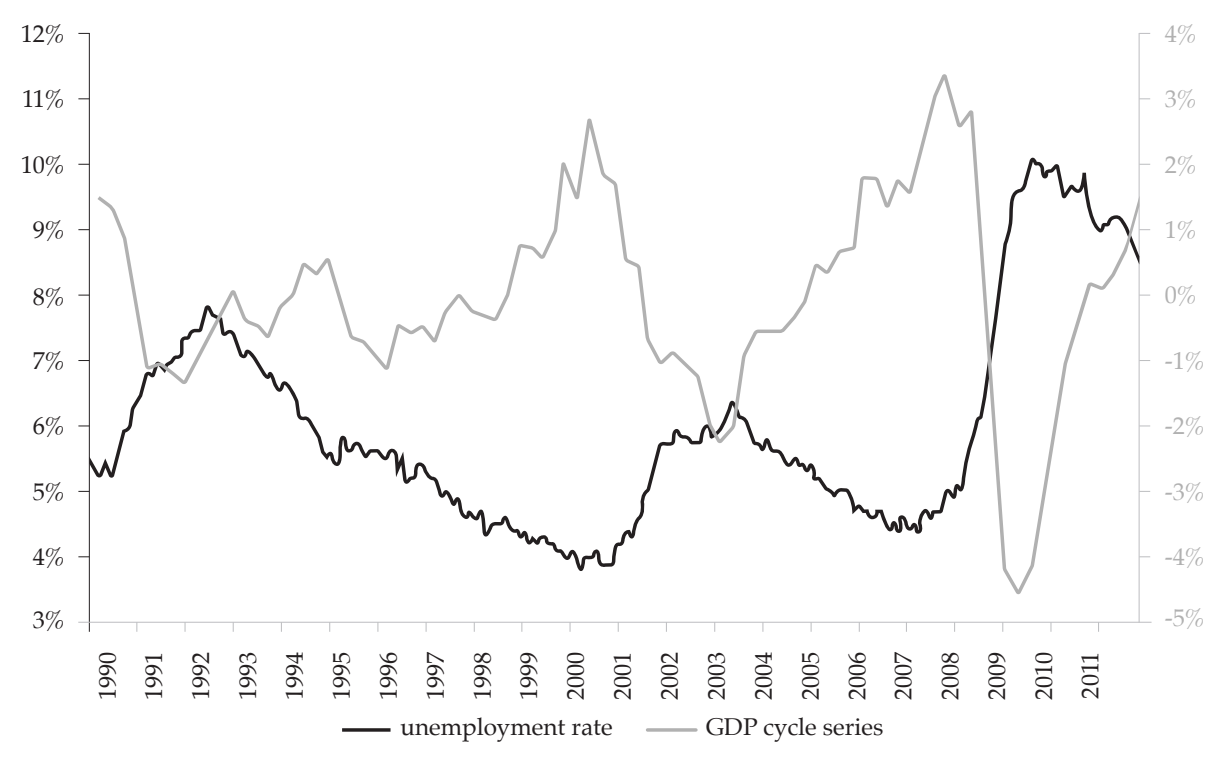

Figure 2. US Unemployment and GDP Cycle (Monthly)

Nevertheless, this type of co-movement between the credit and economic cycle is far from new. Aliaga-Díaz and Pía (2010) - see also: Reinhart and Rogoff (2009), Bordo (2008) and Mendoza and Terrones (2008) — have found evidence in line with this by proving the counter-cyclical behavior of interest rates. This implies that during crisis, credit is less accessible (due to higher interest rates), reducing investment and worsening the recession.

The connection between credit and the economic cycle is closely related to what is referred to in the literature as the "credit crunch" and "financial accelerator". These two terms are often used to explain the effect of the financial system in economic crisis. The credit crunch refers to a significant

1 GDP cycle is obtained using the Hodrick Prescott filter with $\lambda=14400$. 
reduction in credit supply; the financial accelerator has been explained as the amplification of initial shocks due to changes in the credit market.

Bernanke and Lown (1991) mention a set of arguments that could explain the credit crunch in the US 1990 crisis. Among the many reasons offered by the authors, "overzealous regulation" and "credit demand and borrowers' balance sheets" fit quite well into the events of the last six years - even though the authors did not choose the aforesaid as the main factors for the 1990s credit crunch - . The former refers to a strict behavior from banks during the economic crisis in order to reduce risky credit that could lead to loan losses. This kind of behavior directly downsizes credit. The second point argues that during crisis, credit demand slows down. One of the many reasons for it is the weakening of borrowers' balance sheets, which is affected by lower prices. The latter argument becomes more relevant after the most recent crisis. As shown in figure 3, real house prices have been constantly decreasing since the outbreak of the subprime crisis.

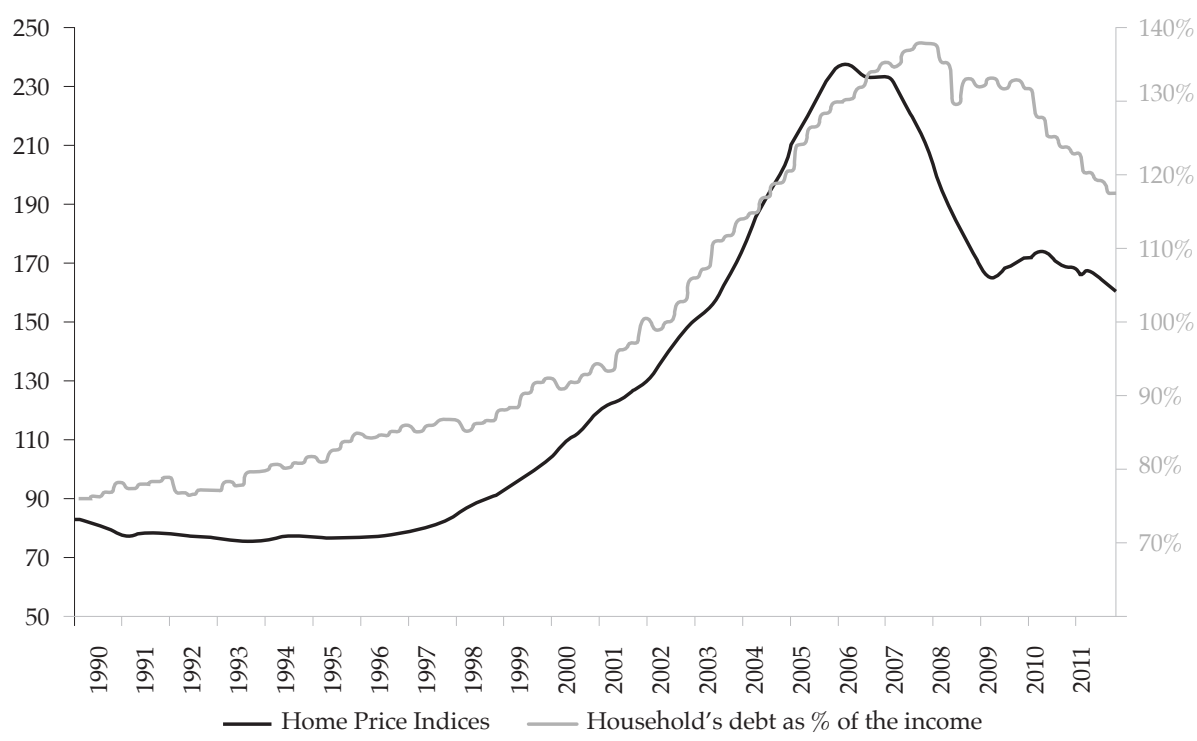

Figure 3. Case-Shiller Home Price Indices and Household's Debt as \% of the Income (Monthly)

As shown by Arango et al. (2011), one of the reasons that could induce an economic crisis after the bursting of a price bubble is a protracted underpricing of goods used as collateral, particularly land prices. This phenomenon reduces collateral for a long period, increasing the length and seriousness of the credit crunch. 
Using some recent developments from the Dynamic Stochastic General Equilibrium (DSGE) literature on the housing market, this paper develops a DSGE model that explains how a financial system's collateral constraint can amplify negative economic shocks in an expansive monetary environment, reducing monetary policy impact on the economic activity.

A word on the limitations of this research is due. This manuscript limits its analysis of monetary policy to the use of the interest rate instrument. As such no-conventional monetary policy, like the ones observed in the United States and Europe in the aftermath of the 2008 crisis, are beyond the scope this paper and subject matter for further research. In this sense, the effectiveness of the monetary policy is defined as the impact of interest rates on economic activity, especially on production, since the model presented in this manuscript includes prices, along with some rigidities on the price setting process (sticky prices), but no shocks on inflation.

\section{Credit Crunch and Financial Accelerator}

A credit crunch has usually been thought of as a consequence of economic downturns instead of a cause of economic fluctuations. One of the consequences of a financial system is the presence of larger fluctuations due to the monetary accelerator. The seminal work of Bernanke et al. (1996) refers to two complementary characteristics of the financial accelerator: the amplification of initial shocks and its propagation. The main reason behind these two consequences is the worsening of the financial conditions of the agent. In particular, a flight to quality reduces access to the financing of the most vulnerable agents in the economy, restraining their capacity to smooth consumption.

Bernanke and Gertler (1989) illustrate some of the financial accelerator effects by showing how Real Business Cycle (RBC) fluctuations can reduce cash flow to borrowers, and later through investment, to the rest of the economy, which generates a vicious cycle that amplifies the effect of the initial shock and prolongs it to the following periods.

Greenwald and Stiglitz (1993) reached a similar conclusion using a model where companies can only operate with debt. They found that a company whose access to financing reduced suffers a decrease in its production and profits, which in turn induces a decline in income to the rest of the economy. Gertler (1992) and Aghion and Bolton (1997), among other authors, found the same effects with different models.

Bernanke et al. (1998) mention information asymmetries to be one of the main reasons for the financial accelerator. They also cite agency costs and the fact that, under credit market frictions, borrowers' finance premiums depend 
inversely on their wealth, reinforcing the conclusion that an exogenous reduction of household income restrains access to credit.

In line with Bernanke et al. (1998), Aoki et al. (2004) present a model with frictions in the credit market that includes housing services as part of consumption. They found that a positive shock in the economy increases the demand for houses and, therefore, house prices rise, which in turn improves house owners' net worth, allowing them to borrow more money, increasing the demand for houses even further.

Considering a different perspective, Kiyotaki and Moore's (1997) seminal paper introduces a collateral constraint for borrowing, describing a different crisis propagation mechanism through credit. In this type of model, crisis generates a decrease in the price of any goods used as collateral, causing a reduction in borrowing capacity; therefore, lower spending.

The Kiyotaki and Moore's set up has been widely used in more recent papers, such as Kocherlakota (2000), Monacelli (2009), Iacoviello (2005), Calza et al. (2009), Brzoza-Brzezina and Makarski (2011), and Arango et al. (2011), among others, due to the recent surge on interest in the relationship between credit and the price of goods used as collateral. Most of these papers use New Keynesian DSGE models that illustrate how the financial system can amplify the initial effect of productivity or monetary policy shock. Many of those models relay on Calvo (1983) pricing set up in order to simulate the effect of the price of durable goods on a collateral constraint.

Most of the literature after Kiyotaki and Moore's paper has taken collateral constraint as an exogenous term. Brzoza-Brzezina and Makarski (2011) go further on this, presenting a DSGE model that introduces a credit constraint that, in an exogenous way, becomes more restrictive and in turn causes a credit crunch.

In the same vein of the financial accelerator literature, this paper describes a model where financial markets amplify economic shocks. Other important studies for the development of this paper are referenced below. Nevertheless, the literature on the credit-market is vast, and the review presented here is far from being a complete survey. Bernanke et al. $(1996 ; 1998)$ can be referenced for further consultation.

\section{The Price Bubble}

Wrong pricing is not an idea with which many economists feel comfortable. Nevertheless, price bubbles are mostly related to this term. The last us crisis was an example of incorrect pricing, as reported in various journals: "We economists were wrong: Even when traders in an asset market know the value 
of the asset, bubbles form dependably. Bubbles can arise when some agents buy not on fundamental value, but on price trend or momentum" (Gjerstad \& Smith, 2009).

Bubbles don't spring from nowhere. They're usually tied to a development with far-reaching effects: electricity and autos in the 1920s, the Internet in the 1990s, the growth of China and India. At the outset, a surge in the values of related businesses and goods is often justified. But then it detaches from reality (Lahart, 2008).

What this section is trying to say is that a price bubble usually only looks like irrational behavior after it bursts. In the meantime, as prices rise and peak, it looks like a sustainable situation. In the words of the former chairman of the FOMC, Alan Greenspan:

this vast increase in the market value of asset claims is in part the indirect result of investors accepting lower compensation for risk. Such an increase in market value is too often viewed by market participants as structural and permanent (Krugman, 2005).

The pricing behavior mentioned above leads to larger consequences that extended to the economy as a whole. As stated by some analysts, the bursting of the house price bubble plays a crucial role when the economy crashes:

In the absence of home-price appreciation, many households are finding it difficult to refinance their way out of adjustable-rate mortgages obtained at the height of the housing boom. Larger mortgage payments could exacerbate delinquencies and foreclosures, especially with interest rate resets expected to remain high for the next year (DiMartino \& Duca, 2007).

Some of this trouble might have been avoided if home prices had continued to climb like they did between 2000 and 2005. As a home appreciates, even borrowers who aren't paying the principal loan amount build up more equity. That in turn would have made it easier for subprime borrowers to refinance into yet another loan with a low interest rate (Associated Press, 2007). 
These two statements reflect the main idea of this paper, which focuses on the bursting of the price bubble. ${ }^{2}$

\subsection{Financial System's Cautious Behavior}

A financial system will often take many precautions, such as the analysis of payment affordability and a credit score, among others. Still, the only precaution that remains useful after default is collateral, although the sole action of asking for it can be seen as cautious behavior. Under Kiyotaki and Moore's approach, only one percent of the asset is useful as collateral (usually $75 \%$ ). This proportion is constant and therefore makes it harder to make the financial system tighten its behavior. Since all these situations are examples of cautious behavior to one degree or another, in this paper, for simplicity, collateral taken at a certain percentage will be as such called. ${ }^{3}$

This paper presents a model where the collateral constraint, unlike in previous literature, is endogenous and describes the financial system's decisions. This, along with a "naive pricing" scheme, as proposed in Arango et al. (2011), generates an amplifying effect like the one described by the financial accelerator literature. However, unlike most conventional wisdom, the financial accelerator is not driven by the interest rate. As a consequence, this paper's contribution is to simulate a credit crunch in a low-interest rates environment so that monetary policy has no significant effect.

After this brief introduction, four more sections complete this paper: section two presents the DSGE model, section three presents the parameter calibration, section four shows the simulation results, and section five draws conclusions.

\section{The Model}

The representative households that use durable and non-durable goods construct the economy described in the model. They obtain their income from several sources dividable into three groups: productive factors, benefits, and credits. There are three types of productive factors: labor, capital, and land, all used by companies and owned by households. They produce intermediate goods that are later used by companies to produce the final goods consumed

2 A description of the boom and consequent burst in a price bubble can be found in Arango et al. (2011).

3 Lower percentages will imply a less lax behavior. 
by the households. The intermediate companies are slightly differentiated and produce benefits delivered to the owners.

Credits have to be paid within a certain time after they are acquired, with an interest rate set by the monetary authority. In this way, the monetary authority provides all the liquidity needed to sustain a Taylor rule based interest rate. Credit is provided through a financial system that works under perfect competition, having no markup on the interest rate. Nevertheless, the financial system demands collateral for lending, determined by land price, which is equivalent to the present value of the future rent of the land. This closes the production and credit cycle, summarized in figure 4 .

\section{Households}

A typical household is described by infinitive lifetime utility horizon given by:

$$
E_{0}\left\{\sum_{t=0}^{\infty} \beta^{t} U\left(x_{t}, n_{t}\right)\right\}
$$

Where $N t$ is the borrowers' total hours worked and $X_{t}$ is the consumption index, which is a bundle of non-durable $\left(C_{t}\right)$ and durable $\left(d_{t}\right)$ consumption, described by:

$$
X_{t}=\left[\left(1-\alpha_{h}\right)^{\frac{1}{v c}}\left(c_{t}\right)^{\frac{v c-1}{v c}}+\left(\alpha_{h}\right)^{\frac{1}{v c}}\left(d_{t}\right)^{\frac{v c-1}{v c}}\right]^{\frac{v c}{v c-1}}
$$

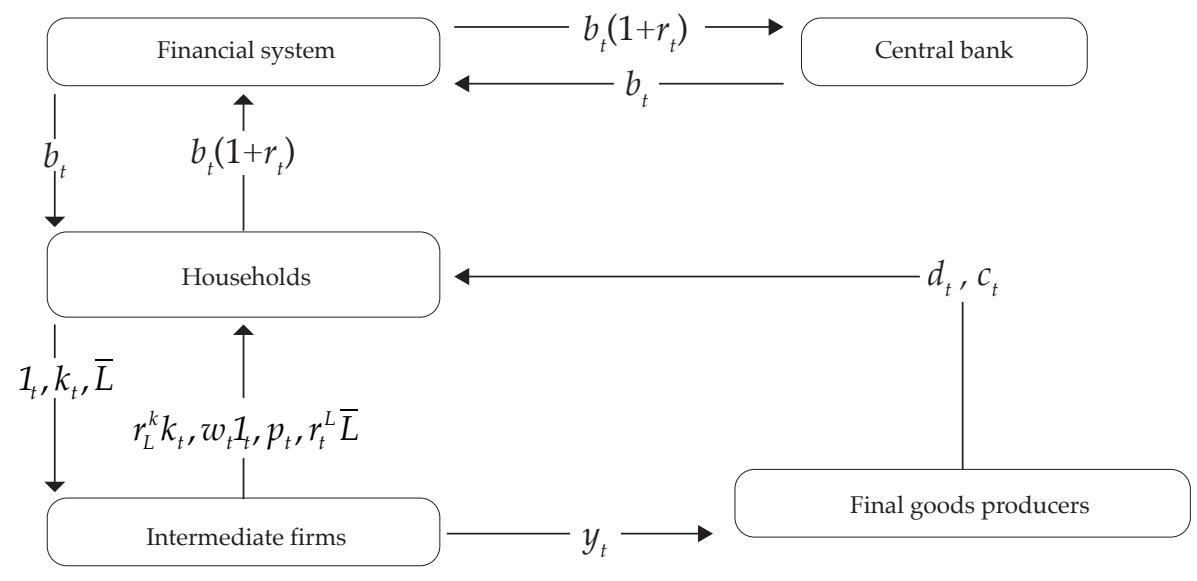

Figure 4. The Model 
Also, it will be assumed that utility is a constant relative risk aversion function described by:

$$
U\left(x_{t}, n_{t}\right)=\frac{\left(x_{t}\right)^{1-\sigma}}{1-\sigma}-\varphi \frac{l_{t}^{1+\mu}}{1+\mu}
$$

Household's decisions are subject, at any time, to an inter-temporal budget constraint that, expressed in units of the non-durable goods, is:

$w_{t} l_{t}+r_{t}^{k} k_{t}+p_{t}+b_{t}+r_{t}^{L} \bar{L}+\left(1-\delta_{h}\right) q_{t} d_{t-1}+\left(1-\delta_{k}\right) k_{t-1} \geq\left(1+r_{t}\right) b_{t-1}+c_{t}+d_{t} q_{t}+k_{t}$

Where at every period $t: W_{t}$ is the salary; $r_{t}^{K}$ the capital's rent, $k_{t}$ the capital; $p_{t}$ intermediate firms benefits; $\bar{L}$ y $r_{t}^{L}$ the land and it's rent; $b_{t}$ the debt acquired every period; $r_{t}$ the interest rate; ${ }^{4} \delta_{h}$ and $\delta_{k}$ the durable goods and capital's depreciation rate, and $q_{t}$ durable goods price. Finally, $\pi_{t}^{c}$ is the change in the price of the consumption good; given that every variable is expressed in terms of the consumption good, $\pi_{t}^{c}$ is the measure of inflation.

Following Kiyotaki and Moore (1997), household's borrowing decision is also constrained to its collateral endowment, this is:

$$
b_{t}\left(1+r_{t}\right) \leq X_{t} E_{t}\left(\zeta_{t}\right)
$$

Where $E_{t}(\zeta t)$ is the expected value of land and $X_{t}$ is the proportion of land's value usable as collateral; as in Monacelli (2009), collateral constraint saturates in the proximity of the steady state, making equation (5) equality. Given that land is a productive factor, its value is determined by the present value of future productivity:

$$
E_{t}\left(\zeta_{t}\right)=\sum_{h=0}^{\infty} \beta^{h} E_{t}\left(r_{t+h}^{L} \bar{L}\right)
$$

$$
41+r_{t}=\frac{1+i_{t}}{1+\pi_{t}^{c}}
$$


Following closely Arango et al. (2011), land's value is set on a naive ${ }^{5}$ way, in which lands value depends on the present value of future land's revenue, this is: 6

$$
E_{t}\left(\zeta_{t}\right)=\sum_{h=0}^{\infty} E_{t}\left(\beta^{h} r_{t}^{L} \bar{L}\right)=r_{t}^{L} \bar{L} \frac{1}{1-\beta}
$$

Equation (7) assumes that the market sees transitory productivity shocks as permanent, which is in line with the behavior described in "The Price Bubble" section. Nevertheless, as the shocks disappear, equation (7) implies that land prices return to its unchanged steady state.

Household's decisions on consumption of labor, capital and borrowing are:

$$
\begin{gathered}
\lambda_{t}=\left(x_{t}\right)^{-\sigma} x_{t}^{\frac{1}{v}}(1-\alpha)\left(c_{t}\right)^{\frac{-1}{v}} \\
0=\left(x_{t}\right)^{-\sigma} x_{t}^{\frac{1}{v}}(\alpha)^{\frac{1}{v}}\left(d_{t}\right)^{-\frac{1}{v}}+\lambda_{t+1} \beta\left(1-\delta_{h}\right) q_{t+1}-\lambda_{t} q_{t} \\
\varphi^{l \frac{\mu}{t}}=\lambda_{t} w_{t} \\
\lambda_{t}=\lambda_{t} r_{t}^{k}+\lambda_{t+1} \beta\left(1-\delta_{k}\right) \\
\beta \lambda_{t+1}\left(1+r_{t+1}\right)=\lambda_{t}+\lambda_{t} \gamma_{t}\left(1+r_{t}\right)
\end{gathered}
$$

Where $\lambda_{t}$ is the shadow price of real income that, as shown in equation (8), is equivalent to the marginal utility of non-durable consumption.

\subsection{Final Good Producers}

Final good producers transform the intermediate good $\left(y_{j t}\right)$ in both durable and non-durable goods $\left(y_{i t}=c_{t}, d_{t}\right)$, using the same technology described by the following bounder:

5 The naive pricing scheme proposed by the authors supposes that, at any moment, market's land valuation is done assuming that future land's revenues would stay unchanged in the future $\left(r_{t}^{L}=r_{t+1}^{L}=r_{t+2}^{L}=\cdots\right)$ as if the present is the steady state.

6 Given that $0<\beta<1$ expresion $\sum_{h=0}^{\infty} \beta^{h}$ is equal to $\frac{1}{1-\beta}$. 


$$
\left[\int_{0}^{1} y_{j t}^{\frac{\theta}{\theta-1}} d_{j}\right]^{\frac{\theta}{\theta-1}}=y_{i t} \text { for } i=d, c
$$

Those firms minimize their cost determined by the input price $\left(P_{i t}\right)$ subject to equation (13). The standard cost minimization implies the following intermediate good demand:

$$
y_{j t}=\left(\frac{p_{j t}}{P_{t}}\right)^{-\theta} y_{i t}
$$

Where $P_{t}$ is the aggregated price level given by:

$$
P_{t}=\left[(1-w)\left(P_{j}\right)^{1-\theta}+(w)\left(P_{t-1}\right)^{1-\theta}\right]^{\frac{1}{1-\theta}}
$$

\subsection{Intermediate Good Firms}

A typical firm $j$ operates a Cobb-Douglas production function given by:

$$
y_{j, t}=z_{t} k_{j, t}^{1-\alpha-v} n_{j, t}^{\alpha} \bar{L}_{j}^{v}
$$

Where $z_{t}=z_{t-1}^{\rho_{z}} z^{1-\rho_{z}} e^{\varepsilon^{\frac{z}{t}}}$ describes the technology process, which depends on a normal distributed shock.

Firms minimize their cost subject to their production function, this is:

$$
\frac{\min }{l_{j t} k_{j t}} \omega_{t} l_{j, t}+r_{t}^{k} k_{j, t}+r_{t}^{L} \bar{L}_{j}-\eta_{j t}\left(y_{j, t}-z_{t} k_{j, t}^{1-a-v} n_{j, t}^{a} \bar{L}_{j}^{v}\right)
$$

Where $\eta_{j t}$ is the intermediate good production's marginal cost. First order conditions attaining capital, land and labor are:

$$
r_{t}^{k}=\eta_{j t}(1-\alpha-v) \frac{y_{j, t}}{k_{j, t}}
$$




$$
\begin{gathered}
\omega_{t}=\eta_{j t} \alpha \frac{y_{j, t}}{l_{j, t}} \\
r_{t}^{L}=\eta_{j t} v \frac{y_{j, t}}{l_{j}}
\end{gathered}
$$

\subsection{Intermediate Goods Pricing}

Intermediate goods firms also select their prices following a Calvo pricing restriction. This means that, at any period $t$, only a proportion 1- $w$ of the firms can adjust their prices. Price setting is determined by the following profit maximization problem.

$$
\frac{\max I I_{t}}{P_{i t}} \sum_{i=0}^{\infty}(\beta \omega)^{i}\left(\left(\frac{P_{j t}}{P_{t}+i}\right)-\eta_{j t+i}\right) y_{j t+i}
$$

The solution to this optimization problem is:

$$
\frac{P_{j t}}{P_{t}}=\frac{\theta}{\theta-1}\left(\frac{\sum_{i=0}^{\infty}(\beta \omega)^{i} \eta_{j t+i}\left(\frac{P_{t+i}}{P_{t}}\right)^{\theta} y_{t+i}}{\sum_{i=0}^{\infty}(\beta \omega)^{i}\left(\frac{P_{t+i}}{P_{t}}\right)^{\theta-1} y_{t+i}}\right)
$$

Equation (22) is the firm's $j$ relative price that, along with (15), summarizes the solution to (21).

\subsection{Financial System}

A financial system under perfect competition means that no benefit is obtained from its activities. Nevertheless, to stay in the market, financial institutions must take measures that allow them to have a safe lending activity. It means that collateral must be enough to cover the debt at any time, a situation that is particularly difficult to attain when collateral prices are in a downward dynamic. From now on the condition that enables a complete collateral coverage of the debt's value will be referred to as safe lending condition (SLC), which implies that at any time: 


$$
\left(1+r_{t}\right) b_{t-1} \leq \zeta_{t}
$$

As said before, this type of condition is overruled by equation (5) during positive fluctuations, since lands price will be always larger; hence, enough to cover the debt and its cost.

The collateral value can be expressed at any time as a function of its dynamics:

$$
\zeta_{t}=k_{t} \bar{\zeta}
$$

Where

$$
k_{t} \varepsilon(0, \infty)
$$

As mentioned before, a financial system problem arises when land value is below debt total value; this is:

$$
\frac{\left(1+r_{t}\right) b_{t-1}}{\zeta_{t}}>1
$$

Using (24), equation (26) can be expressed as:

$$
\frac{\left(1+r_{t}\right) b_{t-1}}{\bar{\zeta}}>k_{t}
$$

The sLc problem is that credit's approval is given one period before its payment, making it impossible to know the collateral coverage over the debt if defaulted, when credit conditions are established. In this order, we have that if credit is approved in $t$, SLC is:

$$
\begin{aligned}
& \left(E_{t}\left[1+r_{t+1}\right]\right) b_{t} \leq E_{t}\left[\zeta_{t+1}\right] \\
& \left(E_{t}\left[1+r_{t+1}\right]\right) b_{t} \leq E_{t}\left[k_{t+1}\right] \bar{\zeta}
\end{aligned}
$$

Assuming one more time naive pricing, this is: 


$$
\begin{aligned}
& \left(1+r_{t}\right) b_{t} \leq k_{t} \bar{\zeta} \\
& \frac{\left(1+r_{t}\right) b_{t}}{\bar{\zeta}} \leq k_{t}
\end{aligned}
$$

A similar condition is found in (5), where $X_{t}$ is readable as a variable that undervalues current lands price in order to guarantee the complete coverage of debts in the next period. Following this interpretation, sLC can be expressed as a condition on $X_{t}$. Using equation (5) and (29), we have that a sufficient condition for SLC is:

$$
x_{t} \leq k_{t}
$$

Or

$$
x_{t} \leq \frac{\zeta_{t}}{\bar{\zeta}}
$$

Following the later and using $k_{t}$ as $X_{t}^{\prime}$ s argument, $X_{t}$ must fit the following conditions

$$
x_{t}=\left\{\begin{array}{l}
1 \cdot f\left(k_{t}\right) \in(0,1) \forall k_{t} \in(0, \infty) \\
\text { 2. } f\left(k_{t}\right)=0 \Leftrightarrow k_{t}=0 \\
\text { 3. } f\left(k_{t}\right) \leq k_{t} \forall k_{t} \in(0, \infty)
\end{array}\right.
$$

The first condition constrains equation (5) to the literature standards of $X_{t}$ between 0 and 1 , given that $k_{t}$ can only take positive values; the second one keeps the credit to zero when there is no value in the collateral, and the third allows for equation (30) to be met.

The specific equation with these conditions is the following:

$$
x\left(k_{t}\right)=\left(\frac{e^{k_{t-\vartheta}}}{1+e^{k^{t^{-\vartheta}}}}-\phi\right)(1-\phi)^{-1}
$$

Where $\vartheta$ and $\phi$ are chosen to fit conditions (32) as shown in figure 5 . 


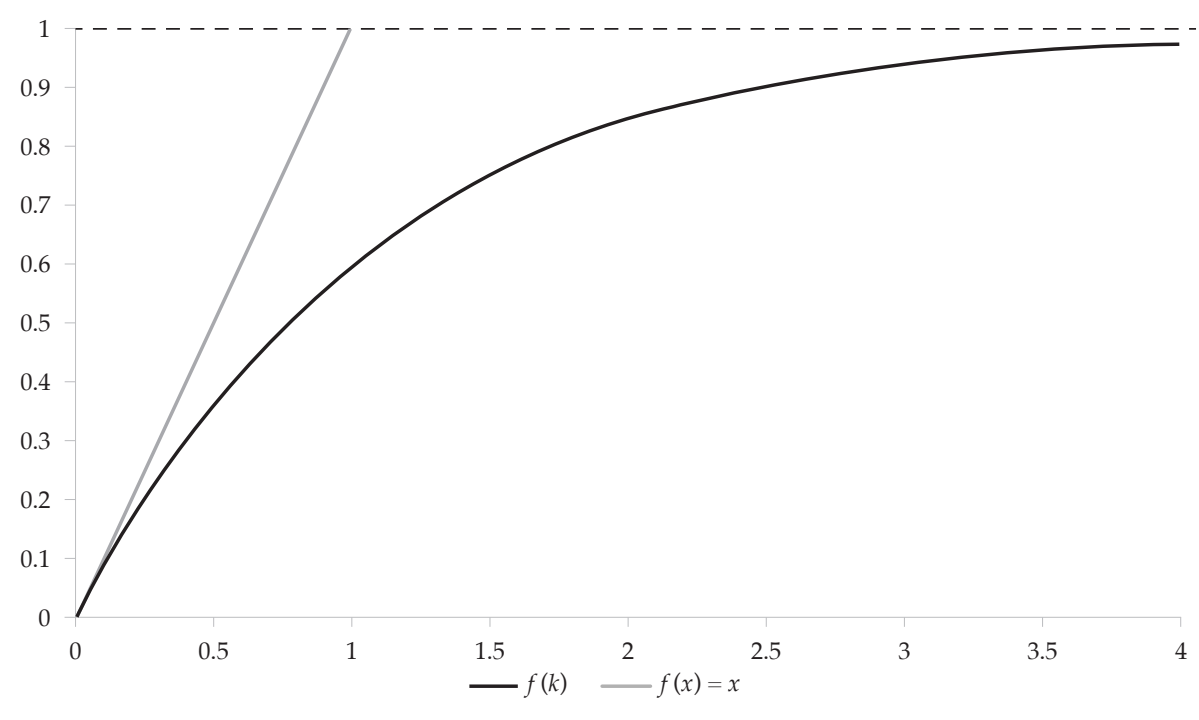

Figure 5. Mapping of $X\left(k_{t}\right)$

\subsection{Monetary Policy}

The monetary policy follows a standard Taylor rule determined by the consumption goods inflation, described by:

$$
r_{t}=\bar{r}\left(\frac{\pi_{t}^{c}}{\bar{\pi}}\right)^{\varphi}\left(\frac{y_{t-n}}{\bar{y}}\right)^{(1-\varphi)}
$$

Where $\vartheta$ determines the weight of inflation in the dual objective interest rate rule.

\section{Calibration}

Calibration of the model is done following some literature standards. Most of the works used for this are built to replicate the US economy This paper is intended to illustrate the transmission mechanism through which the financial system can amplify negative economic shocks in a low-interest rates environment. So as prediction power is not an issue a non-controversial calibration, like the one presented in this section, serves well this paper's purpose.

Among some works, Faia and Monacelli (2007) and Monacelli (2009) were closely followed to choose the parameters' value. Some other papers are mentioned in table 1 . 
Table 1. Calibration

\begin{tabular}{ccl}
\hline Parameter & Values & \\
\hline$\beta$ & 0.99 & $\begin{array}{l}\text { Monacelli (2009); Krusell and Smith (1998); Faia and Monacelli } \\
\text { (2007), and Galí (2008). }\end{array}$ \\
$\delta$ & 0.025 & $\begin{array}{l}\text { Monacelli (2009); Campbell and Hercowitz (2006), and Faia and } \\
\text { Monacelli (2007). }\end{array}$ \\
$\theta$ & 6 & $\begin{array}{l}\text { Monacelli (2009), and Faia and Monacelli (2007). } \\
\alpha_{\mathrm{h}}\end{array}$ \\
$v$ & 0.27 & $\begin{array}{l}\text { Monacelli (2009), and Carlstom and Fruest (2006). } \\
\alpha\end{array}$ \\
0.16 & Kocherlakota (2000). \\
$\omega$ & $1 / 3$ & Faia and Monacelli (2007), and Campbell and Hercowitz (2006). \\
$\sigma$ & 0.75 & Faia and Monacelli (2007), and Monacelli (2009). \\
$\mu$ & 1.5 & Smets and Wouters (2003). \\
$x$ & 1 & Gali (2008) and Walsh (2010). \\
$\varphi$ & 0.75 & Monacelli (2009). \\
\hline
\end{tabular}

Households discount factor $\beta$ is set equal to 0.99 , which means that the discount rate is 0.03 in a quarterly basis. Labor and lands share in the production function are in that order $\alpha=0.33$ and $v=0.16$. Capital is ad durable goods depreciation factor; $\delta_{\mathrm{k}}$ and $\delta_{\mathrm{h}}$ are both equal to 0.025 .

The elasticity of substitution among productive sectors is given by $\theta=6$. The elasticity of substitution between durable and non-durable goods $\left(v_{c}\right)$ is set to 1.4. Durable goods share in the consumption bounder is $\alpha_{h}=0.27$. The chance of price adjustment $(\omega=0.75)$ implies that it occurs every four quarters. ${ }^{7}$ Consumption and labor weights in the utility function are given by $\alpha=1$ and $\mu=1$. Finally, it is assumed that only $75 \%$ of the land can be used as collateral $(X=0.25)$.

As mentioned before, $\vartheta$ and $\phi$ are chosen to fit conditions (32) this is $\vartheta=1.93$ and $\phi=0.87$. All other parameters that are taken from the literature are summarised in table 1.

$$
7 \quad \frac{1}{1-\omega}=4
$$




\section{Results}

This section presents the model's results under two different conditions: fixed and variable $X_{t}$. The first case describes a collateral constraint very similar to the one in Kiyotaki and Moore, where the proportion of lands value as collateral is always constant (I will refer to this case as fixed: $b_{t}\left(1+r_{t}\right) \leq \bar{X} E_{t}\left(\zeta_{t}\right)$ ).

The second case is the one described (5) where a downward trend on land's value increases the financial system's awareness and so reduces the credit slackness, as described by equation (33), reducing households' access to new credits at any interest rate (I will refer to this case as variable).

Figures 6 and 7 show the response of different variables to a shock in technology given by a $1 \%$ decrease in $\varepsilon_{t}^{z}$ in period $t=0$. Figure 6 shows that a $1 \%$ negative shock in technology caused an even larger reduction in production due to the so call financial accelerator, as reflected in the borrowing's dynamics (figure 7).

From a demands point of view, the negative shock reduces land's productivity, causing an even larger reduction in its value due to the naive pricing assumption, which strongly restrains credit extending the reduction effects to durable consumption and capital investment. Particularly, capital shows a very pronounced decrease highly linked to the durable goods dynamics that, opposite to the non-durable goods, show an increase after the production shock. Both capital and non-durable goods are instruments that allow households to transfer wealth from one period to the other. Nevertheless, unlike capital behavior, durable goods profitability is never affected by the technology shock, making households substitute capital with durable goods. From a supply point of view, the negative $\varepsilon_{t}^{z}$ shock reduces all productive factors rent, shrinking the household's supply of all of them, especially of capital as said before. This reduces production and, therefore, consumption and investment.

As mentioned before, figures 6 and 7 show the effects whit a fixed $\bar{X}$ and variable $X_{t}$ described in equation (33). Both figures show that SLC induces an even deeper fluctuation, particularly on the credits' dynamics. However, the production downsize during the first period is only 1.075 times bigger than under variable $X_{t}$; this difference diminishes during the following periods. The fact that this situation is common to all the variables allows concluding that most of the financial accelerator effect simulated by the model is explained by the collateral value and no so much by the financial system's cautious behavior. A similar remark is found in Bernanke et al. (1991), where address as "overzealous regulation" has a significant impact on lending. On the other hand, borrowers' balance sheets strongly determined by collateral's value, is found to be a valid answer to the weakening of lending activity. 

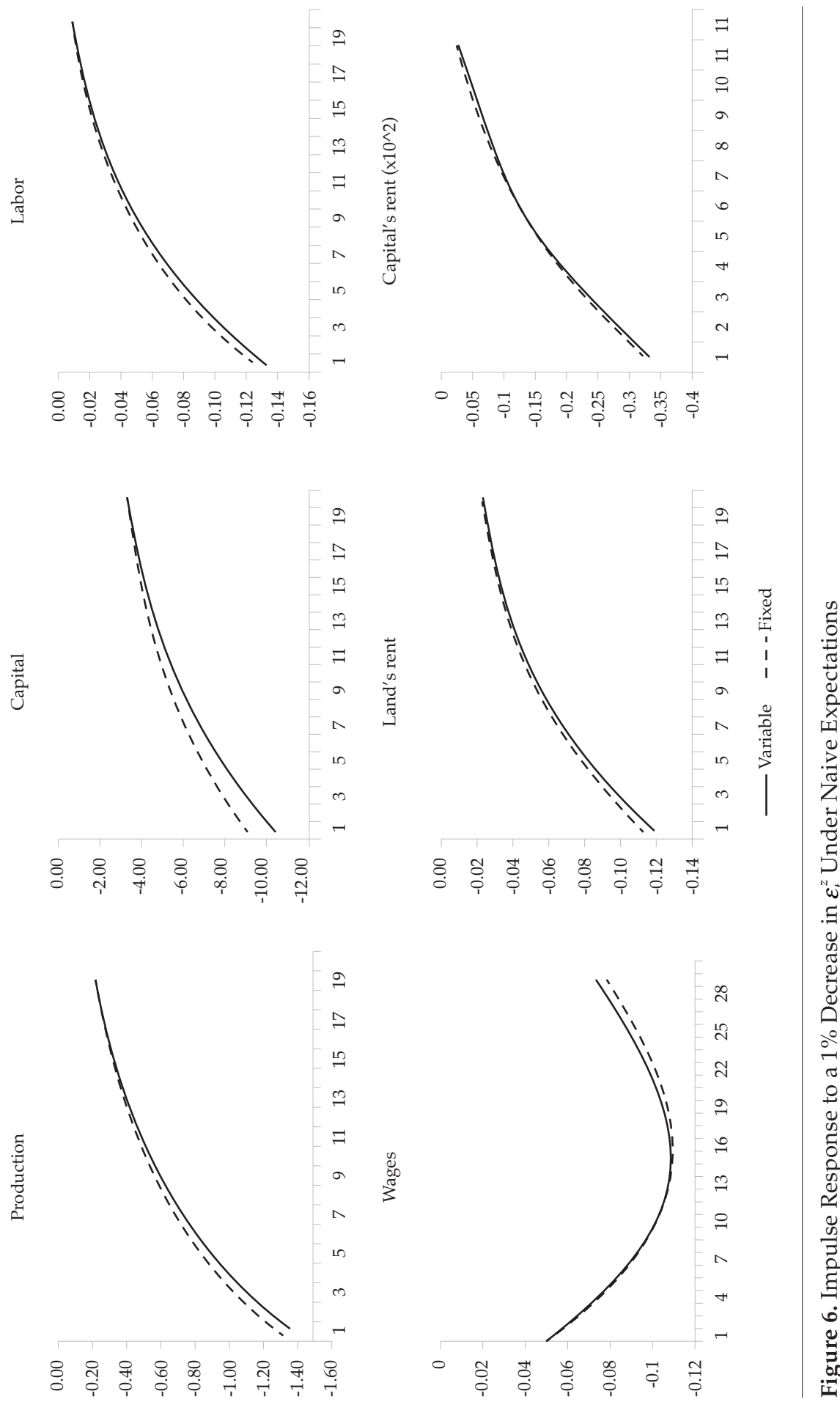

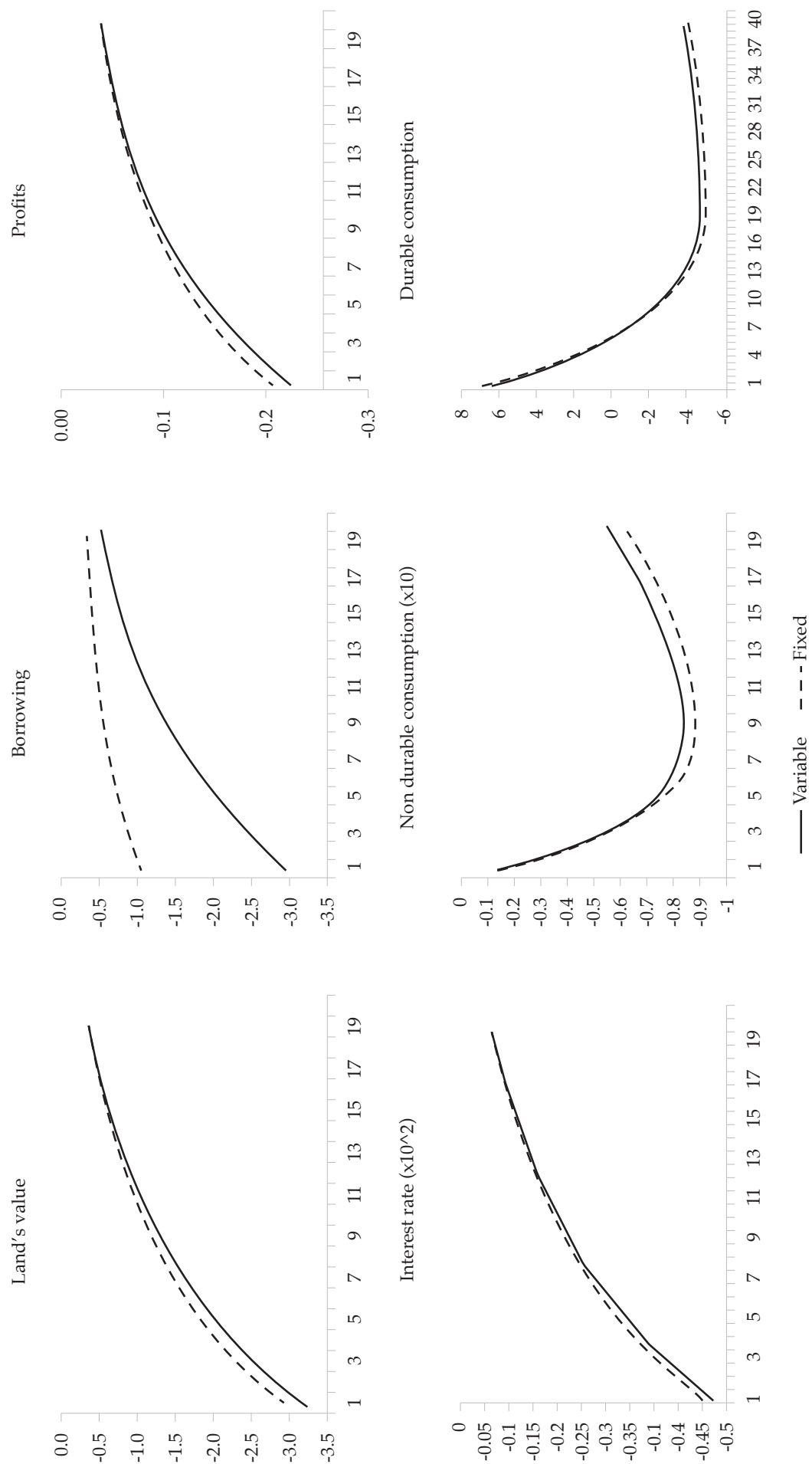
Unlike conventional wisdom, in both cases depicted in figures 6 and 7 production, credit and other variables slowdown despite the low interest rates. The main reason for credit and economy's slowdown is found in the limited access to lending at a low interest rate like one set by the monetary authority. ${ }^{8}$ It is the shortage of warranties offered by the borrowers what explains most of the credit slump.

\subsection{Alternative Monetary Policy}

Simulations in figures 8 and 9 show the effect of an interest rate rule different to (34). This alternative rule uses a bounder of lands prices and the price index of consumption goods, this is:

$$
i_{t}=\bar{l}\left((1-v) \frac{\pi_{t}^{c}}{\bar{\pi}}+v \frac{\zeta_{t}}{\zeta}\right)^{\varphi}\left(\frac{y_{t}}{\bar{y}}\right)^{1-\varphi}
$$

Where $v$ is the weight of land's value in the prices index factor.

As shown in figures 6 and 7, land value is one of the variables that have the strongest reaction after the initial shock. Using (35) causes a greater decrease in interest rates for higher values of $v$. A harder monetary policy should reduce the economy's slump, but, as shown in figures 8 and 9, a more restrictive credit constraint, explained by the collateral value and the financial system behavior, ${ }^{9}$ can stop its expansion effects. Figures 8 and 9 respectively map the impulse response of product and interest for different values of $v$. Figures 10 and 11 show that higher values of $v$ increase the monetary authority reaction to the production shock, through lower interest rates. This effect is hard to acknowledge in figures 8 and 9, which unveils some monetary policy impotence during the economic crisis. It is a consequence of the strong reaction on the collateral that prevents credit recovery despite the low-interest rates.

\subsection{Alternative Land's Valuation Scheme}

Pricing as proposed in equation (7) creates a strong reaction after a productivity shock, allowing to encourage the dynamics of a price bubble burst, as shown in figures 6 to 11 for the land's value. Even if the results are quite

8 A low interest rate rules out a flight to quality or any shortage of financial system's liquidity.

9 Simulations are done using (5). 
compelling, it is interesting to try a different way to determine the land's value in order to prove the exercises robustness.

An alternative pricing scheme must be based on a different expectations formation model; one alternative is adaptive expectations. Following Nerlove and Bessler (2001) one can suppose that at every time $t$ the expected land's revenue is the steady state value plus a portion of the deviation from the one observed in the last period, this is:

$$
E_{t}\left(r_{t+1}^{L}\right)={ }_{r}^{-L}+\Omega\left(r_{t}^{L}-_{r}^{-L}\right) \text { for } 0<\Omega<1
$$

Iterating and replacing (36) in (6), follows that:

$$
E_{t}\left(\zeta_{t}\right)=\bar{L}\left[\bar{r}^{L}\left(\frac{\beta}{1-\beta}\right)+r_{t}^{L}+\left(r_{t}^{L}-\bar{r}^{L}\right)\left(\frac{\beta \Omega}{1-\beta \Omega}\right)\right]
$$

As the reader can notice, equation (7) and (37) are similar in the fact that both depend on the present productivity of land; the difference is that (37) assumes that only a fraction of the present productivity is incorporated in the land's price. It also can be demonstrated that these equations are equivalent in steady state. ${ }^{10}$

Results for this alternative expectations formation model are quite similar to the naive pricing scheme, as shown in figures 12 and $13 .{ }^{11}$ Nevertheless, the price bubble burst depicted in figure 13 is not as string as that of figure 7; this as a consequence of higher transitory information asymmetries in the naive expectations compared to the one with adaptive expectations.

Pricing schemes purposed in equations (7) and (37) are a result of nonrational expectations. Given that under rational expectation, there is by definition non-wrong pricing, there is no place for a bubble burst. This is why a wrong pricing scheme, like the one in equations (7) and (37), is needed in order to illustrate a bubble burst.

10 In steady state:

Equation (7) is: $\sum_{h=0}^{\infty} \beta^{h} r_{t}^{L} \bar{L}=r_{t}^{L} \bar{L}+\beta r_{t}^{L} \bar{L}+\beta^{2} r_{t}^{L} \bar{L}+\cdots=r_{t}^{L} \bar{L} \frac{1}{1-\beta}$.

Equation (37) is: $\bar{L}\left[\bar{r}^{L}\left(\frac{\beta}{1-\beta}\right)+r_{t}^{L}\right]=r_{t}^{L} \bar{L}+\beta r_{t}^{L} \bar{L}+\beta^{2} r_{t}^{L} \bar{L} \ldots$

11 All the other variables have a similar behavior to the one in figures 6 and 7 . 


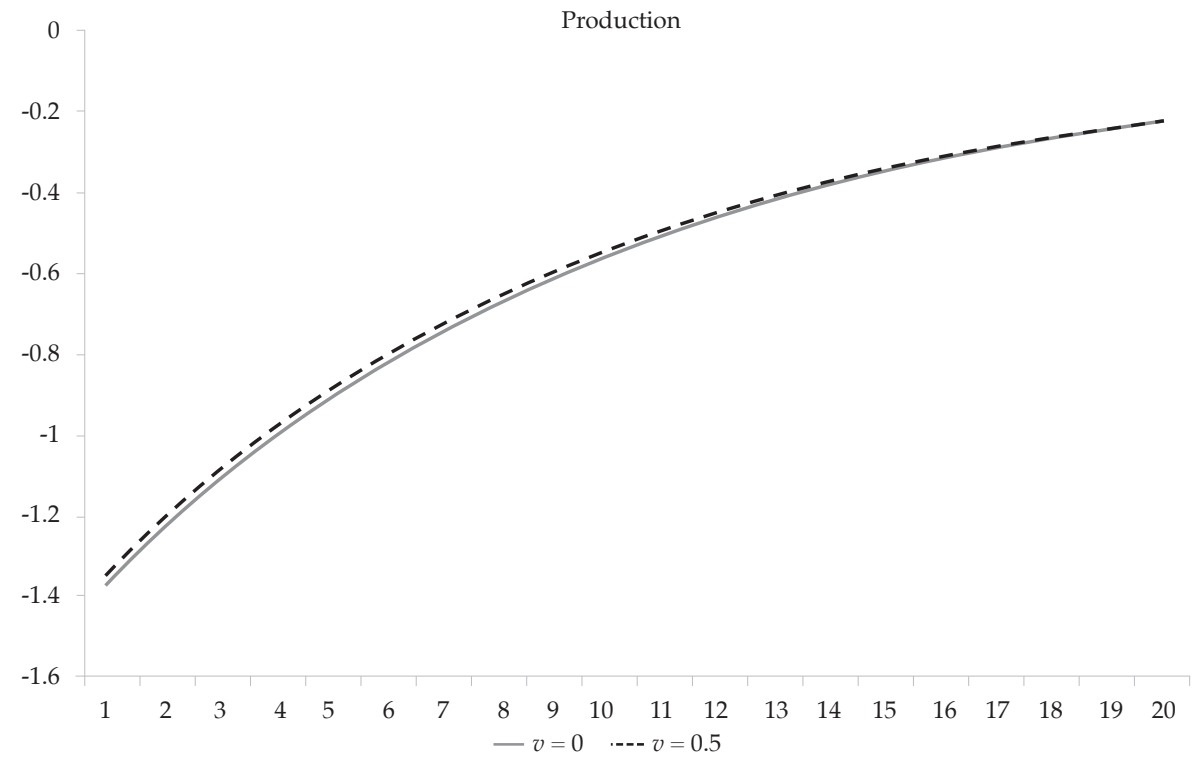

Figure 8. Product Response with $v=0$ and $v=0.5$, to a $1 \%$ Decrease in $\varepsilon_{t}^{z}$ Under Naive Expectations

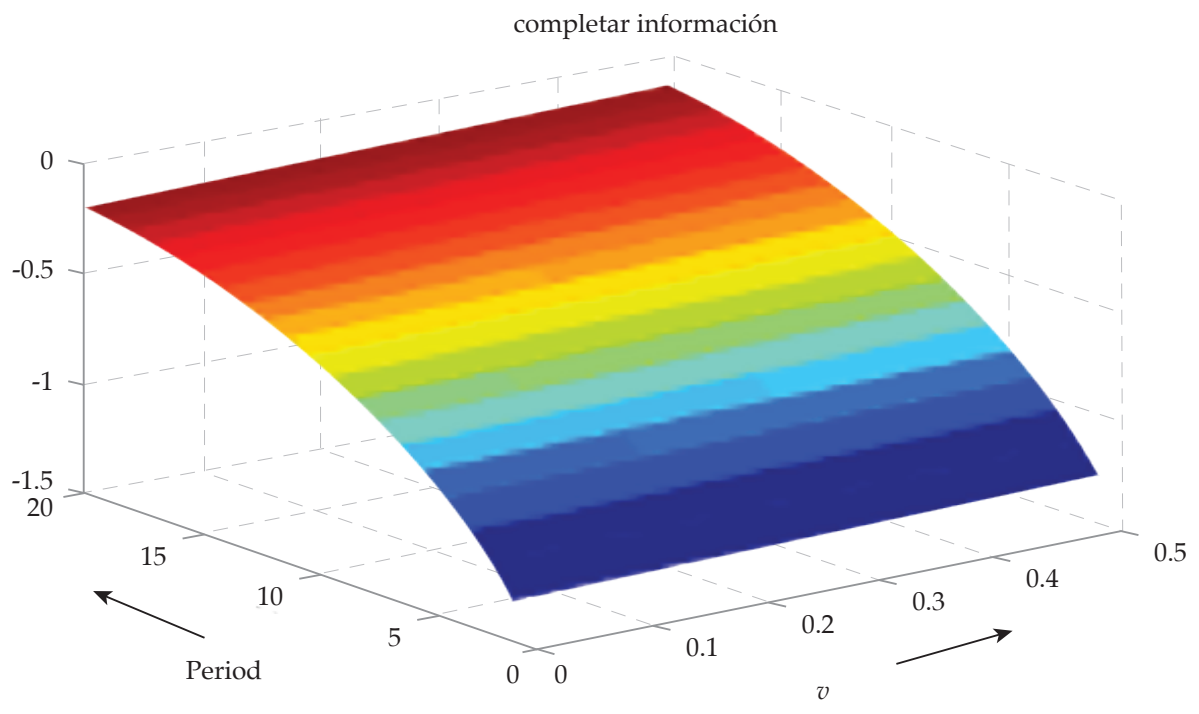

Figure 9. Product Response with Different Values of $v$, to a $1 \%$ Decrease in $\varepsilon_{t}^{z}$ Under Naive Expectations 


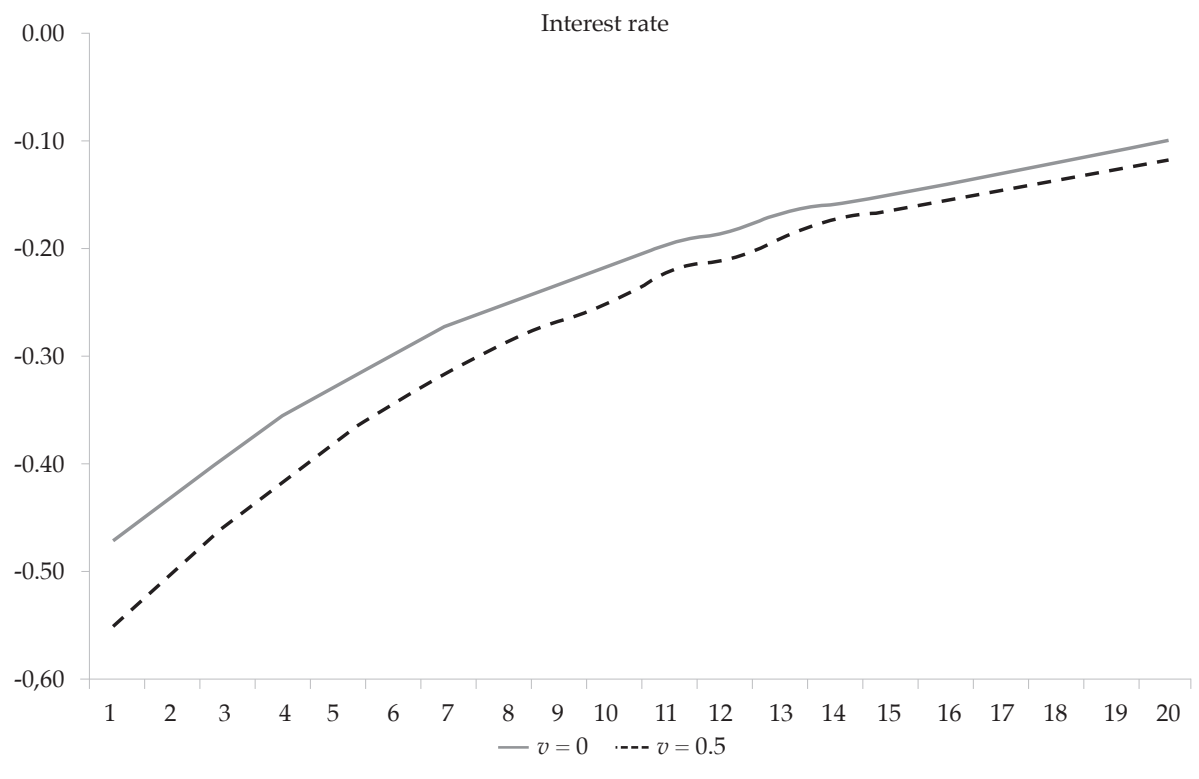

Figure 10. Interest Rate —as in (35) — Response with $v=0$ and $v=0.5$, to a $1 \%$ Decrease in $\varepsilon_{t}^{z}$ Under Naive Expectations

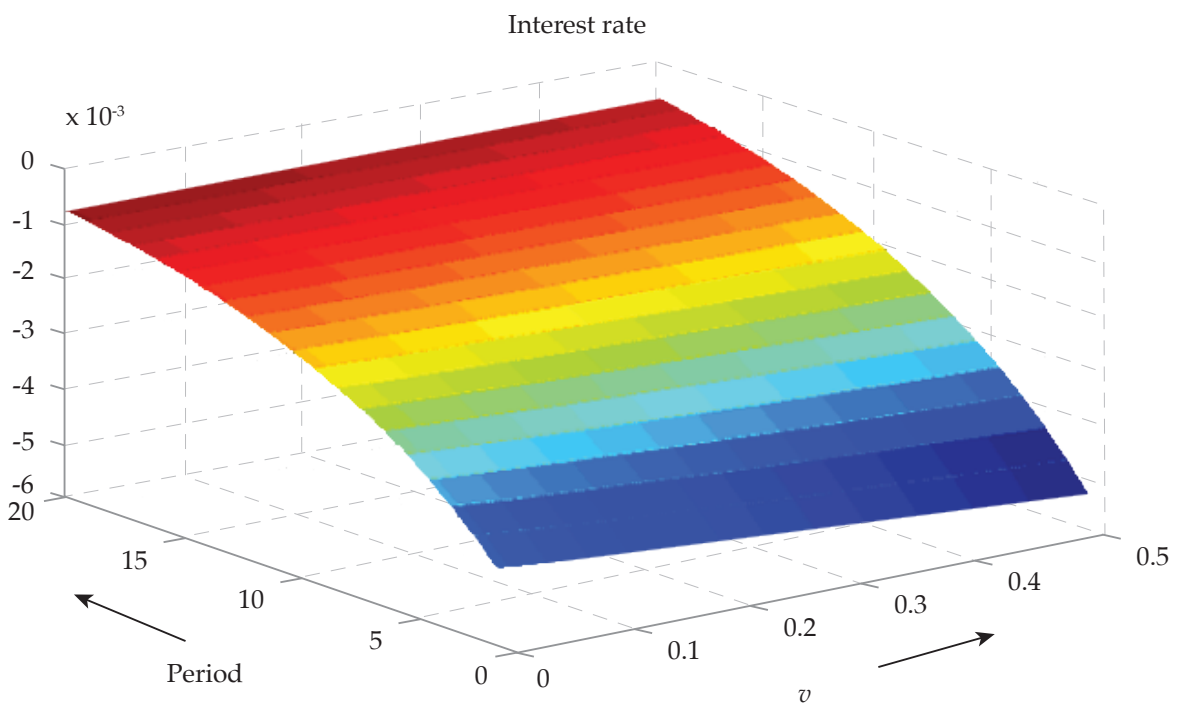

Figure 11. Interest Rate —as in (35) - Response with different Values of $v$, to a $1 \%$ Decrease in $\varepsilon_{t}^{z}$ Under Naive Expectations 

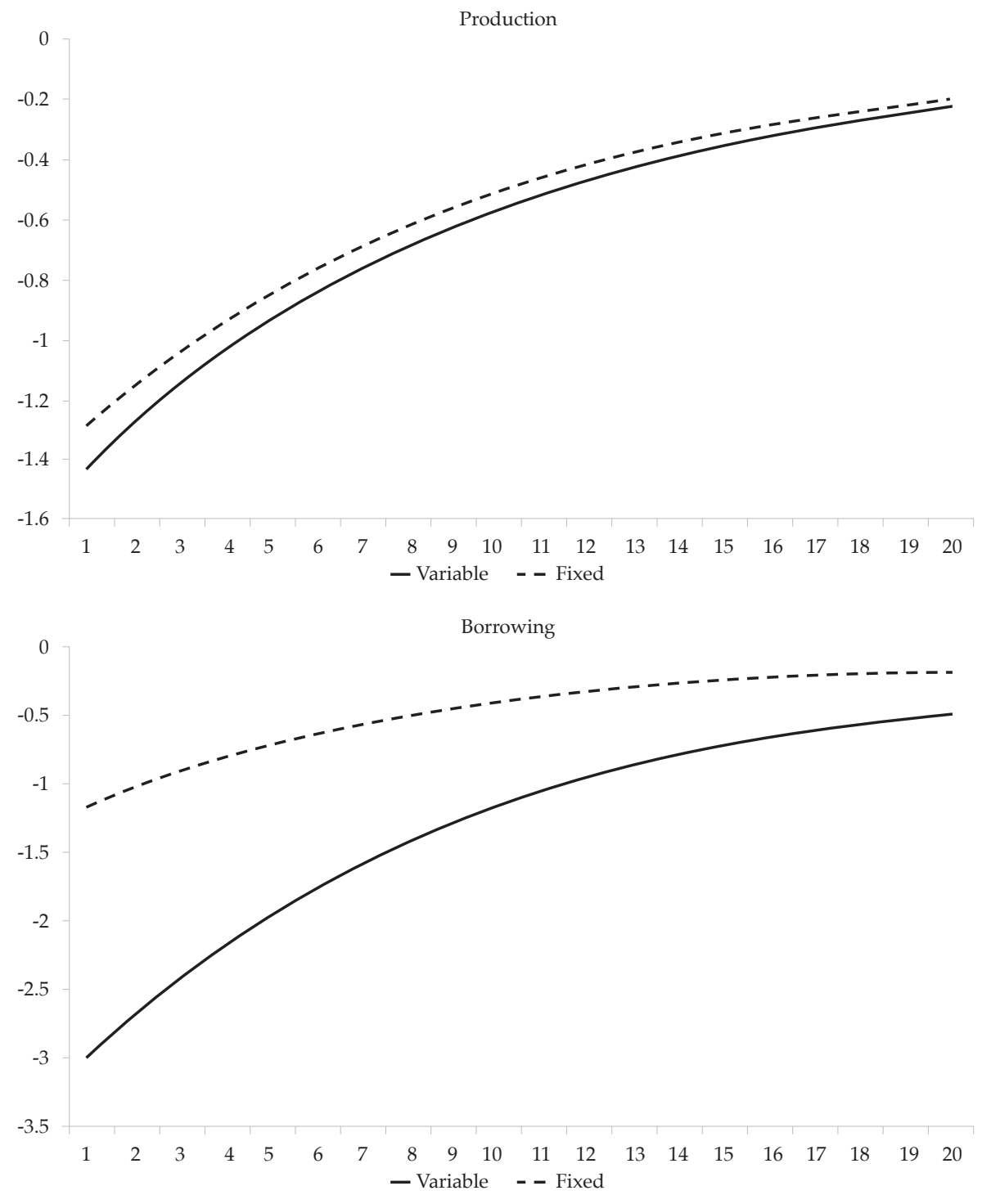

Figure 12. Impulse Response to a $1 \%$ Decrease in $\varepsilon_{t}^{z}$ Under Naive Expectations 

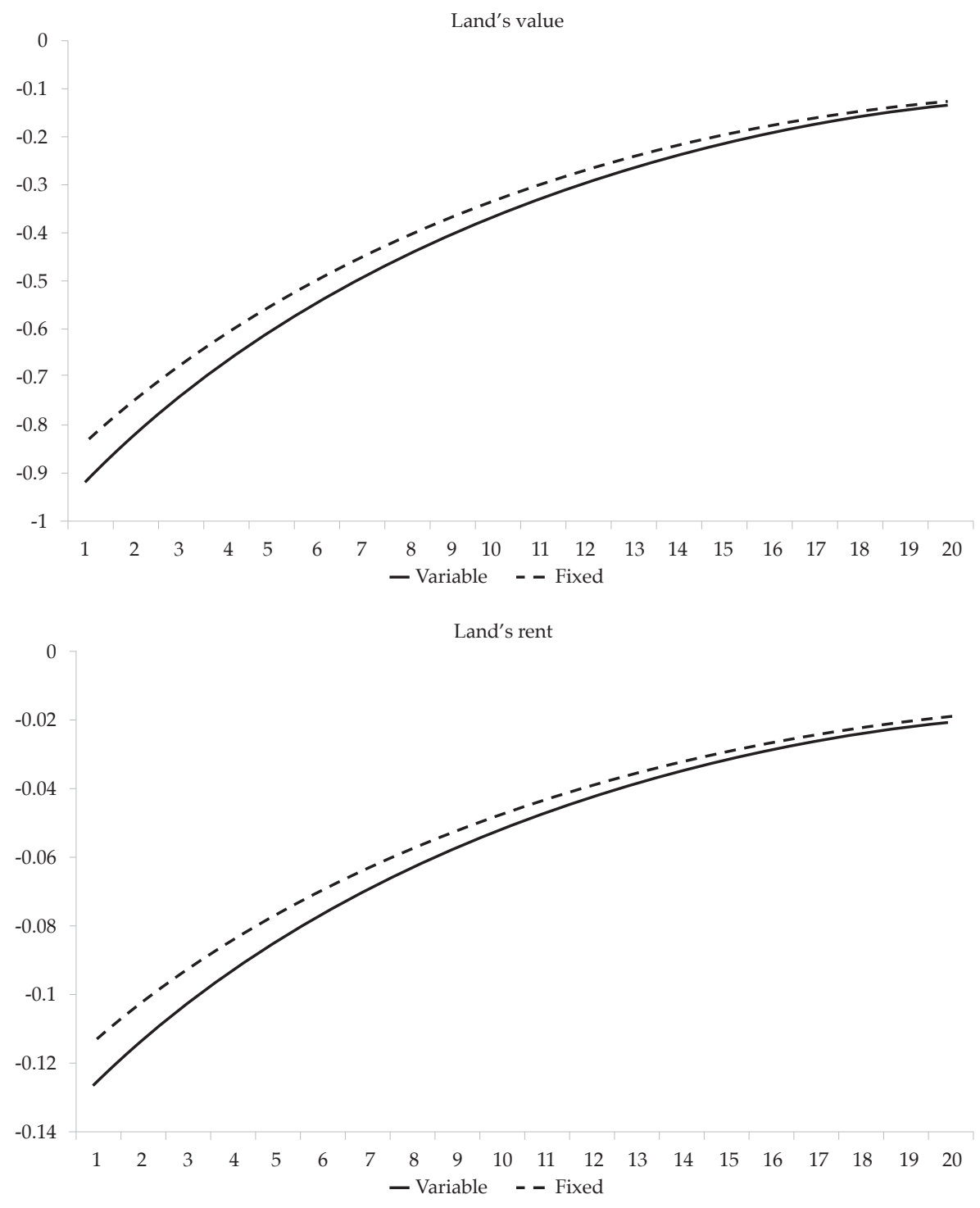

Figure 13. Impulse Response to a $1 \%$ Decrease in $\varepsilon_{t}^{z}$ Under Naive Expectations 


\section{Conclusions}

The model depicts an amplifying effect of credit over the rest of the economy, which is vastly described by the financial accelerator literature. Nevertheless, credit dynamic is determined by the collateral meaning of the collateral value and the financial system's slackness. Taking guaranties for credit approvals can determine credit's dynamic; the first factor plays a more important role than the second.

Under such circumstances traditional monetary policy proves highly inefficient in increasing economic activity, keeping the economy in a sort of "liquidity trap" induced by the low access to credit. As collateral determines the credit's value, asset's price used for this restriction deserves special attention of economic authorities in order to have a higher control on the credit cycle and its power to influence the economic cycle.

The simulations show that the collaterals values can become a strong barrier to the hard monetary policy given that credit approvals need two conditions: asking for it and being worthy. Low-interest rates can make it for the first condition but not for the second. For that reason lowering interest rates in order to improve credit and, thus, house price might not be enough.

This kind of situation showed that the burst of a price bubble on assets used as collateral has larger consequences than let us say the .com bubble. It is also harder to deal with given that monetary policy effectiveness diminishes. This makes that the idea of "buying houses and burn them in order to reduce supply" does not look so unappealing, notwithstanding it is steel unavailable. Some central banks have tried buying unusual assets (for instance, the Bank of Japan has started to intervene in the stock market, and the FEDs' QE programs have also lead to unusual balance sheets); nevertheless, these actions have been quite futile given that these assets are not used as collateral.

The intervention of the monetary authorities in the real estate market can be more distortionary than useful, that is why the attention must be in avoiding price bubbles, at least on assets that usually are used as collateral. In those cases, Greenspan's philosophy of not doing anything and then cleaning the mess might not be the best idea.

\section{References}

Aghion, P., \& Bolton, P. (1997). A theory of trickle-down growth and development. Review of Economic Studies,64(2), 151-72. 
Aliaga-Díaz, R., \& Olivero, M. P. (2010). Is there a financial accelerator in us banking?: Evidence from the cyclicality of banks' price-cost margins. Economics Letters, 108(2), 167-171.

Aoki, K., Proudman, J., \& Vlieghe, G. (2004). House prices, consumption, and monetary policy: a financial accelerator approach. Journal of Financial Intermediation, 13(4), 414-435.

Arango, M., Posada, C. E., \& Tamayo, J. A. (2011). El sistema crediticio, la política monetaria y un posible origen deciclos y crisis financieras. Ensayos Sobre Política Económica, 29(64), 32-61.

Associated Press (March 13, 2007). Will subprime mess ripple through economy? QEA: Looking at the impact of the mortgage meltdown at NBC News. Retrieved from http://www.nbcnews.com/id/17584725/ns/business-real_estate/t/will-subprime-mess-ripple-through-economy/\#.XPrahi1Dl0c Bernanke, B., \& Lown, C. (1991).The credit crunch. Brookings Papers on Economic Activity, 22(2), 205-248.

Bernanke, B., \& Gertler, M. (1989). Agency costs, net worth, and business fluctuations. American Economic Review, 79(1), 14-31.

Bernanke, B., Gertler, M., \& Gilchrist, S. (1998). The financial accelerator in a quantitative business cycle framework. Working Papers 98-03. New York University.

Bernanke, B., Gertler, M., \& Gilchrist, S. (1996). The financial accelerator and the flight to quality. The Review of Economics and Statistics, 78(1), 1-15.

Bordo, M. D. (2008). An historical perspective on the crisis of 2007-2008. NBER Working Papers 14569. Retrived from https://www.nber.org/ papers/w14569.pdf

Greenwald, B. C., \& Stiglitz, J. E. (1993). Financial market imperfections and business cycles. NBER Working Papers 2494. Retrieved from https:// www.nber.org/papers/w2494.pdf

Brunnermeier, M. K. (2008). Deciphering the liquidity and credit crunch 200708. NBER Working Papers 14612. Retrieved from https:/ / www.nber.org/ papers/w14612.pdf

Brzoza-Brzezina, M., \& Makarski, K. (2011). Credit crunch in a small open economy. Journal ofInternational Money and Finance, 30(7), 1406-1428.

Calvo, G. A. (1983). Staggered prices in a utilitymaximizing framework. Journal of Monetary Economics, 12(3), 383-398.

Calza, A., Monacelli, T., \& Stracca, L. (2009). Housing finance and monetary policy. Working Paper Series 1069, European Central Bank. Retrieved from http:/ / citeseerx.ist.psu.edu/viewdoc/download?doi=10.1.1.165 $.4037 \&$ rep $=$ rep $1 \&$ type $=$ pdf 
Campbell, J. R., \& Hercowitz Zvi. (2005). The role of collateralized household debt in macroeconomic stabilization. NBER Working Papers 11330. Retrieved from https:/ / www.nber.org/papers/w11330.pdf

Carlstrom, C. T., \& Fuerst, T. S. (2006). Co-movement in sticky price models with durable goods. Working Paper 0614, Federal Reserve Bank of Cleveland. Retrieved from https: / / www.clevelandfed.org/en/newsroom-and-events / publications / working-papers / working-papers-archives/2006-workingpapers/wp-0614-co-movement-in-sticky-price-models-with-durablegoods.aspx

DiMartino, D., \& Duca, J. V. (2007). The rise and fall of subprime mortgages. Economic Letter, 2(11).

Diamond, D. W., \& Rajan, R. G. (2009). The credit crisis: Conjectures about causes and remedies. American Economic Review, 99(2), 606-610.

Faia, E., \& Monacelli, T. (2007). Optimal interest rate rules, asset prices, and credit frictions. Journal of Economic Dynamics and Control, 31(10), 3228-3254.

Galí, J. (2008). Monetary policy, inflation, and the business cycle: An introduction to the new Keynesian framework. Princeton: Princeton University Press.

Gertler, M. (1992). Financial capacity and output fluctuations in an economy with multi-period financial relationships. Review of Economic Studies, 59(3), 455-72.

Gjerstad, S., \& Smith, V. L. (April 6, 2009). From bubble to depression? The Wall Street Journal. Retrieved from https: / /www.wsj.com/articles / SB123897612802791281

Greenspan, A. (2007). The age of turbulence: Adventures in a new world. Penguin Press Publication. New York.

Iacoviello, M. (2005). House prices, borrowing constraints, and monetary policy in the business cycle. American Economic Review, 95(3), 739-764.

Kiyotaki, N., \& Moore, J. (1997). Credit Cycles. Journal of Political Economy, 105(2), 211-48.

Kocherlakota, N. R. (2000). Creating business cycles through credit constraints. Quarterly Review, Federal Reserve Bank of Minneapolis, 2-10.

Krugman, P. (August 29, 2005). Greenspan and the bubble. The New York Times. Retrieved from https: / / www.nytimes.com/2005/08/29/opinion/ greenspan-and-the-bubble.html

Krusell, P., \& Smith Jr., A.-A. (1998). Income and wealth heterogeneity in the macroeconomic. Journal of Political Economy, 106, 867-896.

Lahart, J. (May 16, 2008). Bernanke's bubble laboratory Princeton protégés of fed chief study the economics of manias. The Wall Street Journal. Retrieved from https:/ / www.wsj.com/articles/SB121089412378097011 
Mendoza, E. G., \& Terrones, M. E. (2008). An anatomy of credit booms: Evidence from macro aggregates and micro data. NBER Working Papers 14049. Retrieved from https:/ /www.nber.org/papers/w14049.pdf

Miller, M., \& Stiglitz, J. E. (2010). Leverage and asset bubbles: Averting armageddon with chapter 11? NBER Working Papers 16817. Retrieved from https://www.nber.org/papers/w15817.pdf

Mishkin, F. S. (2009). Is monetary policy effective during financial crises? NBER Working Papers 14678. Retrieved from https://www.nber.org/ papers/w14678.pdf

Monacelli, T. (2009). New Keynesian models, durable goods, and collateral constraints. Journal of Monetary Economics, 56(2), 242-254.

Nerlove, M., \& Bessler, D. A. (2001). Expectations, information and dynamics. In B. L. Gardner \& G. C. Rausser (Eds.), Handbook of Agricultural Economics, volume 1 (pp. 155-206). Elsevier.

Reinhart, C. M., \& Rogoff, K. S. (2009). The aftermath of financial crises. NBER Working Papers 14656. Retrieved from https://www.nber.org/ papers/w14656.pdf

Smets, F., \& Wouters, R. (2003). An estimated dynamic stochastic general equilibrium model of the Euro area. Journal of the European Economic Association, 1(5), 1123-1175.

Taylor, J. B. (December 1993). Discretion versus policy rules in practice. Carnegie-Rochester Conference Series on Public Policy, 39(1), 195-214.

Taylor, J. B., \& Williams, J. C. (2010). Simple and robust rules for monetary policy. NBER Working Papers 15908. Retrieved from https:/ / www.nber. org/papers/w15908.pdf

Walsh, C. (2010). Monetary theory and policy. Cambridge: The MIT Press. 
